\title{
Determination of nutrient requirements for growth and maintenance of growing pigs under tropical condition
}

\author{
S. S. Paul ${ }^{1 \dagger}$, A. B. Mandal ${ }^{2}$, P. N. Chatterjee ${ }^{3}$, R. Bhar ${ }^{3}$ and N. N. Pathak ${ }^{3}$ \\ ${ }^{1}$ Central Institute for Research on Buffaloes, Nabha-147201, Punjab, India; ${ }^{2}$ Central Avian Research Institute, Izatnagar, Bareilly-243122, UP, India; ${ }^{3}$ Centre of \\ Advance Studies in Animal Nutrition, Indian Veterinary Research Institute, Izatnagar, Bareilly-243122, UP, India
}

(Received 12 March 2006; Accepted 20 September 2006)

Data from 27 feeding trials conducted on growing pigs from different research institutes across India were subjected to mixed model regression analysis to derive requirements of digestible energy (DE), crude protein (CP) and essential amino acids for maintenance and body weight gains. The ranges of maintenance requirements were determined to be: DE 516 to $702 \mathrm{~kJ} / \mathrm{kg} \mathrm{M} \mathrm{M}^{0.75}$, CP 6.98 to 11.62 , lysine 0.431 to 0.664 , methionine 0.265 to 0.458 , methionine + cystine 0.327 to 0.466 , cystine 0.055 to 0.184 , threonine 0.205 to 0.511 , arginine 0.377 to 1.21 , isoleucine 0.241 to 0.775 , leucine 0.604 to 1.54 , phenylalanine + tyrosine 0.496 to 1.33 , tryptophan 0.078 to 0.213 , and valine 0.330 to $0.892 \mathrm{~g} / \mathrm{kg} \mathrm{M}^{0.75}$, respectively for different body weight ranges. The corresponding requirements for $1 \mathrm{~g}$ gain in body weight were: $D E 28.6$ to $38.6 \mathrm{~kJ}, C P 0.27$ to $0.44 \mathrm{~g}$, lysine 0.0071 to $0.0126 \mathrm{~g}$, methionine 0.0047 to $0.0133 \mathrm{~g}$, methionine + cystine 0.0151 to $0.0261 \mathrm{~g}$, cystine 0.0043 to $0.0094 \mathrm{~g}$, threonine 0.0052 to $0.0165 \mathrm{~g}$, arginine 0.0045 to $0.0301 \mathrm{~g}$, isoleucine 0.0023 to $0.0198 \mathrm{~g}$, leucine 0.0150 to $0.0447 \mathrm{~g}$, phenylalanine + tyrosine 0.0091 to $0.0382 \mathrm{~g}$, tryptophan 0.0005 to $0.0044 \mathrm{~g}$, and valine 0.0061 to $0.0222 \mathrm{~g}$. Regression equations had high $\mathrm{R}^{2}$ values (ranging from 0.50 to 0.99 for different estimates), low coefficients of variation, low variance of error estimates and the coefficients were highly significant $(\mathrm{P}<0.001)$. Regressed values were used to develop feeding standards. As the new standards derived in the present study are based on a thorough analysis of a larger database than previous Indian standards, the new feeding standard seems to be more appropriate for India and other tropical countries.

Keywords: energy requirements, nutrient requirements, pigs, protein requirement, tropical climate.

\section{Introduction}

Pigs play a crucial role in the rural economy in many tropical countries. Pigs are recognised as one of the most effective livestock for promoting health and economy of poor people in the developing countries of the world. According to Food and Agricultural Organisation estimate (FAO, 2003), pigs contributed 630 thousand Mtonnes of meat amounting to $10.4 \%$ of total meat produced (6038 thousand Mtonnes) in India from different sources. The tropical developing countries with limited feed resources have to economise feeding of pigs by avoiding their wasteful feeding. Efficient utilisation of nutrients depends on adequate supplies of energy, protein and amino acids, which are of paramount importance in determining the productivity of pigs. Nutrient limitations prevent pigs from attaining their genetic potential. Thus an optimum growth rate and feed utilisation efficiency according to inherent genetic potentiality of a particular category of animal can be achieved

\footnotetext{
${ }^{\dagger}$ E-mail: sspaulcirb@yahoo.co.in
}

only through accurate evaluation of their nutrient requirements. Nutrient requirements not only provide a satisfactory guideline for formulation of rations for rearing the animal but are also used for planning of yearly purchase of feed when feed prices are minimum and also provide guideline in developing supplementary feeding strategies for pigs reared under semi-intensive systems. Nutrient requirements depend on body size and growth or production potentials of animals, environmental condition and quality of feed. Temperature, humidity, sunshine and wind velocity may increase or decrease nutrient needs depending upon region. The nutrient needs of pigs under tropical conditions probably differ from pigs found in temperate countries because of differences in genetic makeup, mature body size, growth rate, quality of feeds and climatic variations. The feeding standards for pigs, which are currently being followed (Indian Council of Agricultural Research, 1998; National Research Council (NRC), 1998) in tropical countries need to be updated and refined further to suit the requirements appropriate to the climate and other local 
factors (feedstuffs quality, breed type, growth rate, etc) as more data on nutrient intake and performance derived from feeding trials are available under different dietary and environmental situations. Several approaches are used for estimation of nutrient requirements. These include energy balance in calorimetric chamber studies, short-term nitrogen $(\mathrm{N})$ and energy balance trials with metabolism trials and comparative slaughter on different feeding levels, factorial approaches from estimates of endogenous $\mathrm{N}$ losses in animals fed on low protein diet and analysis of intake versus performance data in feeding trials. Regression analysis of feeding trial data provides estimates of nutrient requirements of productive animals kept under normal farm feeding condition. This approach is less costly, more convenient and, most importantly, can generate nutrient requirement data for animals kept under a normal production setting, without requiring energy chambers or slaughtering of animals and hence such an approach has been widely used (Ash and Norton, 1987; Abate, 1989; Onwuka and Akinsoyinu, 1989; Yang et al., 1997a and b; Zhang and Coon, 2000; Paul et al., 2002, 2003a, b and 2004; Mandal et al., 2005; Okagbare et al., 2004). The present study was undertaken to determine energy, protein and amino acid requirements of growing pigs employing regression analysis models on combined nutrient intake and performance data of almost all of the experimental feeding trials conducted so far in India under diverse tropical feeding conditions.

\section{Material and methods}

\section{Data collection}

The data on digestible energy (DE) intake, crude protein (CP) intake, amino acid intake, body weight (BW), average daily weight gain (ADG) and ration composition, generated through experimental feeding trials conducted on growing pigs in different research institutes of India were collected from published reports. In some reports information was incomplete with respect to one or more of the essential variables like BW, BW change and nutrient intake. Such reports were excluded. Only those data were admitted that contained complete information with respect to BW, BW changes and nutrient intake. Finally, data from 27 studies (details presented in Table 1) representing 102 different dietary treatment groups and 652 animals were used in the present study. These studies were conducted across a wide range of locations and conditions in India. The ranges of values of different parameters are summarised in the result section. In most of the trials, energy intake was expressed in DE units and protein as CP units.

\section{Animals and feeding management in the feeding trials}

The types of pigs included exotic purebred, indigenous non-descript, indigenous purebred or crossbred (Table 1). In most of the feeding trials pigs were fed in groups of four to 16 pigs ad libitum from a weighed allowance of feed. Out of 27 feeding trials, data from one trial (Soren, 2002) were on 48 individual pigs and for the rest of the studies data were on performance of groups (mostly four to six animals per group). In all the experiments growing pigs (above 2 months of age) were used. In most of the studies the pigs were housed individually in pens which provided a covered area having separate arrangement for feeding and watering and an open enclosure for exercise. In a few studies pigs were housed in groups. The ration components and other details are presented in Table 1.

All animals were supplemented with a mineral mixture and vitamins in the concentrate components. The average composition of the mineral mixture was: calcium , $26 \%$; phosphorus, $4.5 \%$; copper $0.48 \%$; cobalt, $0.009 \%$; manganese $0.08 \%$; iodine (as $\mathrm{KI}$ ) $0.0125 \%$; zinc, $0.8 \%$, sodium chloride, $23.5 \%$. The mineral mixture was included the rate of $1.5 \mathrm{~kg}$ per $100 \mathrm{~kg}$ ration. The average composition (per g) of the vitamin mixture was retinol, $24.8 \mathrm{mg}$; riboflavin $50 \mathrm{mg}$ cholecalciferol $0.3 \mathrm{mg}$. The vitamin mixture was added at the rate of $20 \mathrm{~g}$ per $100 \mathrm{~kg}$ feed. Feed intake was recorded daily in all the experiments. BW was recorded every 2 weeks. Digestion or metabolism trials were also conducted to ascertain the nutritive value of rations in all the trials. In some of the trials, animals were fed individually but only group means were reported. In all the trials digestibility or metabolism trials of 6 to 7 days duration were conducted on individual animals but only group means were reported. During digestion trials pigs were placed in metabolism cages individually for separate collection of faeces and urine. Representative samples of feed offered, residue left and faeces were collected daily, pooled, stored and analysed for proximate principles using standard (Association of Official Analytical Chemists, 1970) procedures. The amino acid composition of the ration was presented in some of the reports. For the rest of the studies, amino acid composition of the rations was calculated based on the amino acid content of different feed ingredients reported by different Indian workers and NRC (1998). Environmental parameters were not recorded in any of the studies. However, on the basis of the geographical locations of the experimental stations (experiment stations are between $13^{\circ} \mathrm{N}$ and $32^{\circ} \mathrm{N}$ latitude; details presented in Table 1), it can be inferred that the climate was tropical, with hot and humid weather for most of the year and yearly temperature ranges from a minimum of $-2^{\circ} \mathrm{C}$ to a maximum of $48^{\circ} \mathrm{C}$.

\section{Estimation of nutrient requirements}

In the present study combined data from crossbreds with improved exotic breeds, indigenous purebreeds and nondescripts were utilised. At present sufficient data on different pig breeds with different lean growth potential are not available to establish separate nutrient requirement for a different lean growth category of pigs, if any, on these animals.

During preliminary analysis, it was observed that regression analysis of whole data resulted in relatively lower overall predictability than when analysis was done 


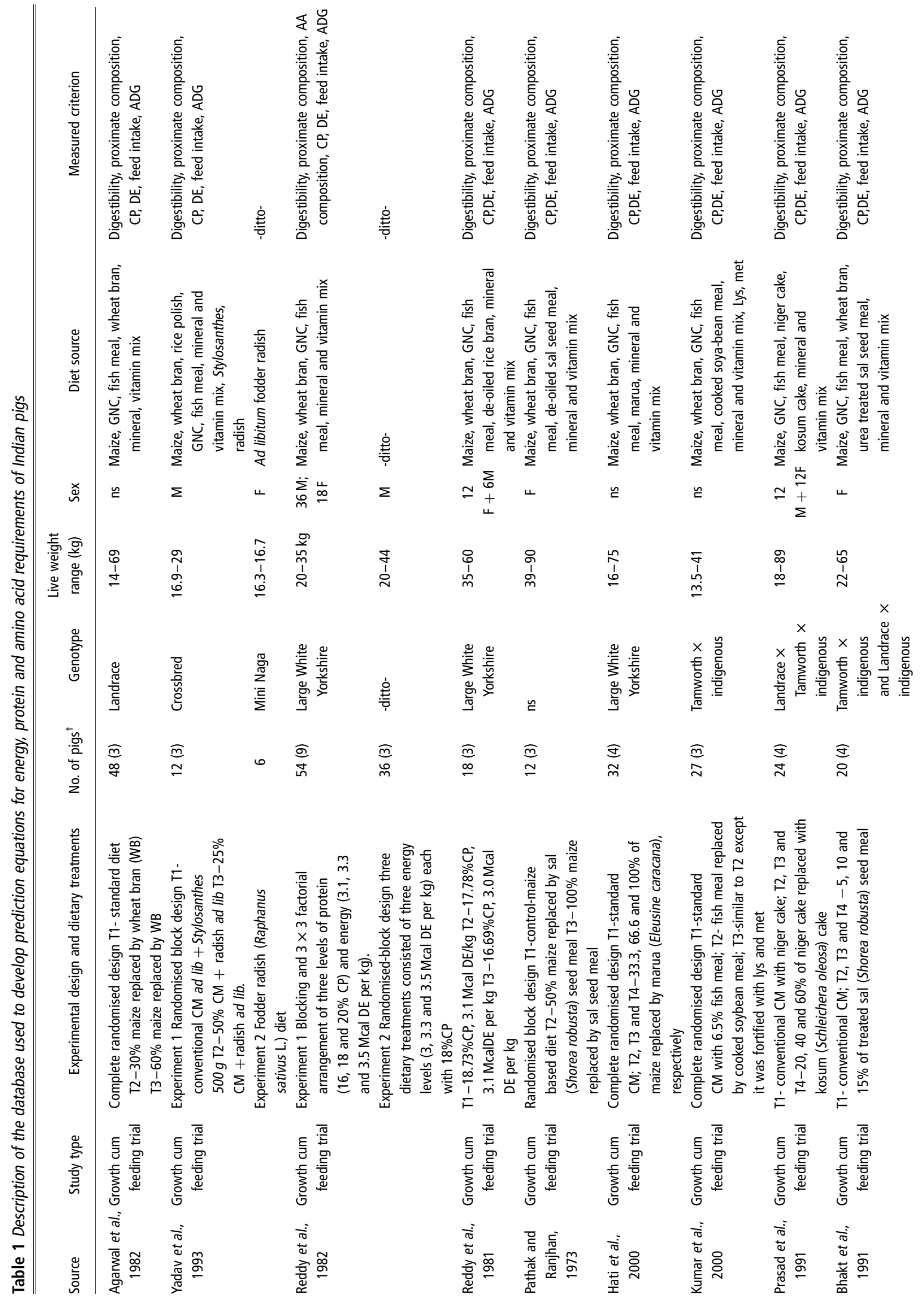




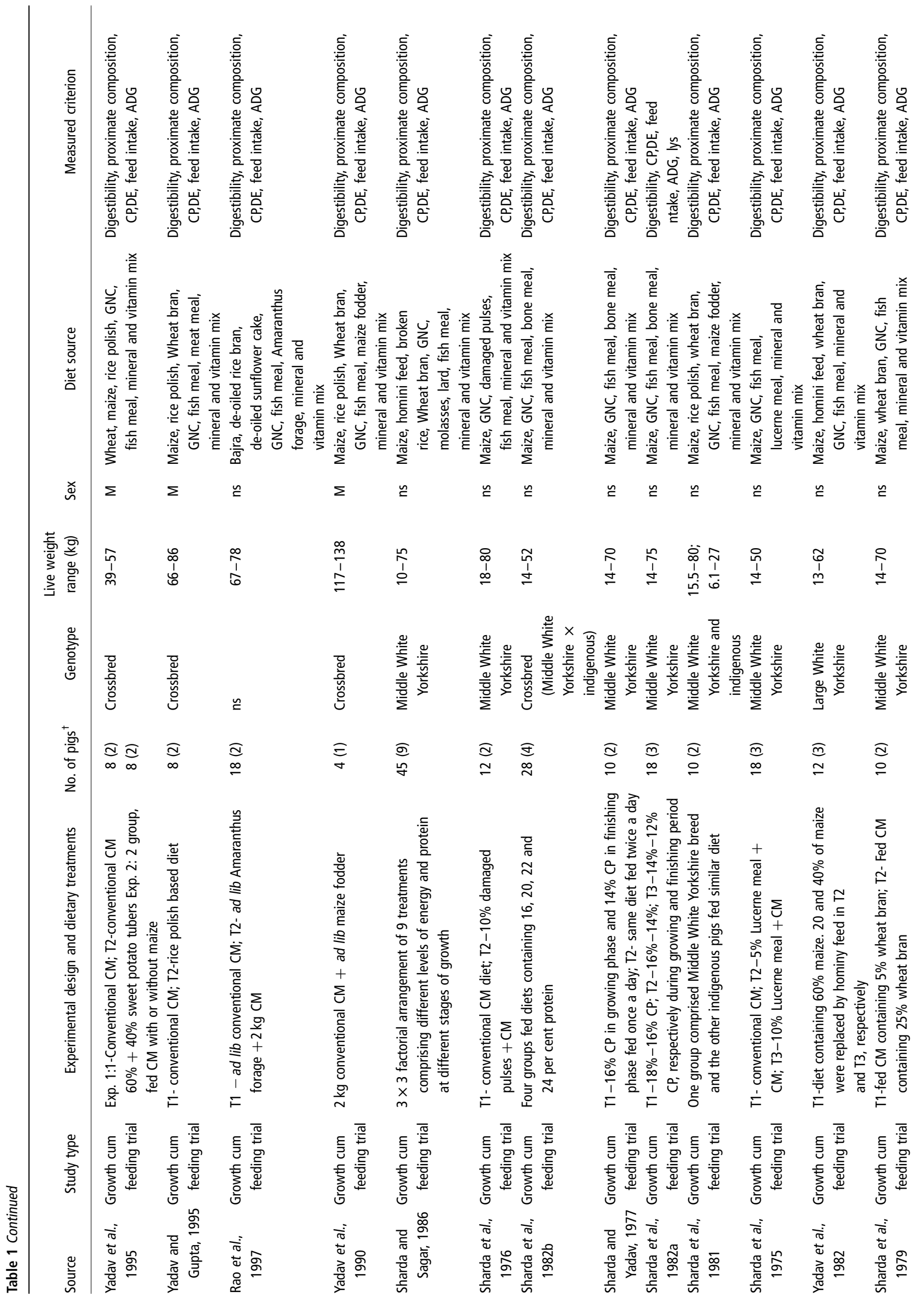




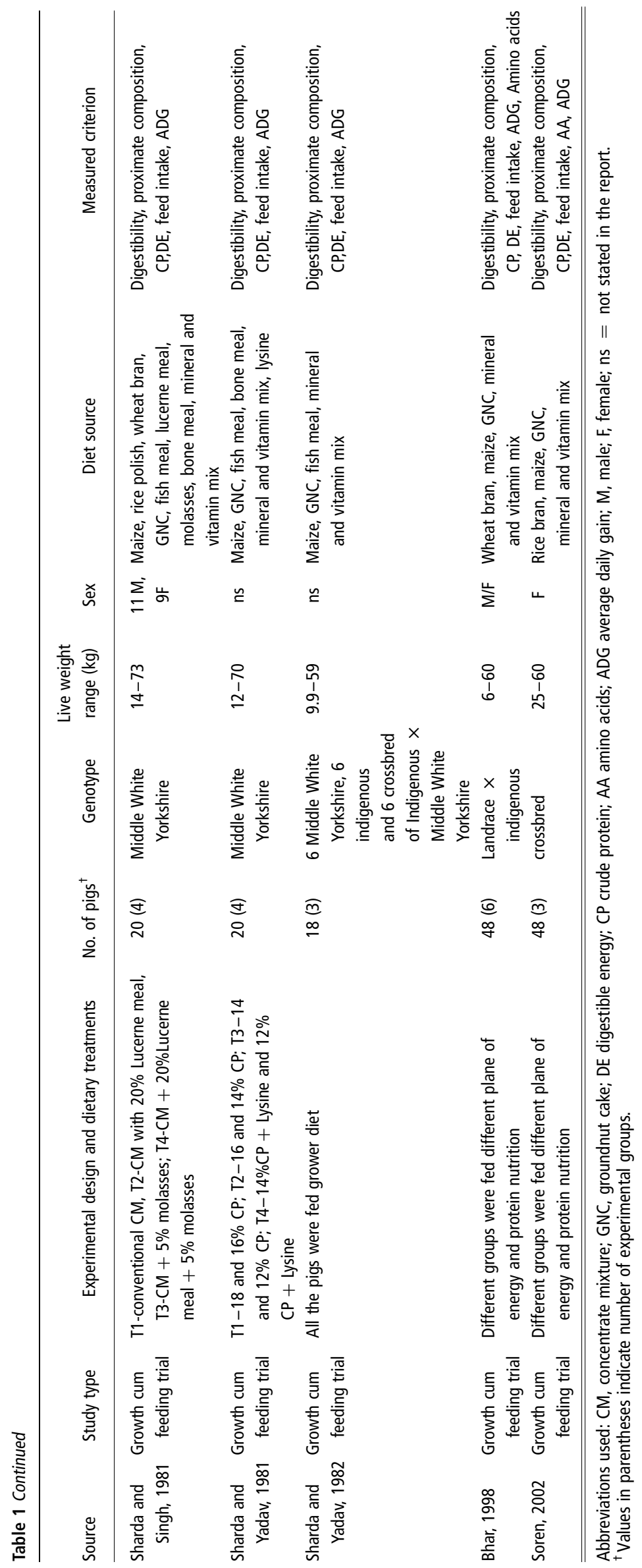


separately for lower and higher BWs and there were substantial differences in estimates obtained at high and low BWs. Homogeneity of regression coefficients for different BW groups were tested using an F test (Steele and Torrie, 1984), which indicated that coefficients were different for different BW ranges groups for one or more nutrients. Hence the experimental data were arranged in four sets, i.e. for 7 to 20,20 to 35,35 to 60 and 60 to $127 \mathrm{~kg} \mathrm{BW}$ for analysis. The BW range classes were as per the existing feeding standards being followed in India for pigs recommended by ICAR (Indian Council of Agricultural Research). The experimental data were subjected to regression analysis using the following model: $Y=a+b X_{1}$, where, $Y$ is intake of $D E, C P$ or amino acids, $\mathrm{kJ}$ or $\mathrm{g}$ per $\mathrm{kg}$ metabolic body weight $\left(\mathrm{M}^{0.75}\right)$ per day; $X_{1}$ is the ADG (g) per $\mathrm{kg} \mathrm{M}^{0.75}$; the intercept, $a$, is an estimate of maintenance requirement; the regression coefficient, $b$ is the estimate of requirements for BW gain ( $\mathrm{kJ}$ or $\mathrm{g}$ per $\mathrm{g}$ gain). A similar model was also used by other workers (Ratray et al., 1974; Abate, 1989; Walter and Mao, 1989; Solis et al., 1991; Paul et al., 2002, 2003a, b and 2004) for estimation of nutrient requirements from feeding trial data.

\section{Statistical analyses}

All regression analyses were performed using mixed liner model procedures (St-Pierre, 2001; Statistical Packages for the Social Sciences (SPSS), 2003). Mixed model analysis was chosen because the data were gathered from various published studies and therefore it was necessary to consider the study effect as a random effect in the context of a metanalytic review (because the studies represent a random sample of a larger population of studies). Mixed effects regression models were constructed with both fixed effects (slope and intercept) and random effects (slope and intercept) for the independent variable. The random effects allowed for the possibility that, in the relationship between dependent and independent variables, each study had its own slope and intercept that varied randomly from study to study. In this context, the slope and intercept from the fixed effects model represent a mean slope and a mean intercept averaged over all studies. In fitting these models, unstructured covariance was utilised. In cases where random covariances were non-significant, a reduced model without a covariance component was fitted. In instances in which the random effect of slope was not significant, slope was removed from the random model. In a mixed effects model, there is no standard definition of $R^{2}$ as in standard (fixed effects) regressions. To assess overall model fit, the general linear model procedure of SPSS (2003) was used to fit a fixed effects regression of the dependent variable on the independent variable. To reflect the presence of random effects in the mixed effects models, a term representing study was added to the model. In addition, in those cases in which a random slope effect was present in the mixed effects model, a term for the interaction of the study and dependent variable was included in the model. The resultant value of $R^{2}$ is reported here. A similar method was also utilised by Broderick and Clayton (1997) for construction of $R^{2}$ for mixed models. The performance of derived prediction equations was evaluated using variance of error estimate $\left(\sigma_{2}^{\text {error }}\right)$ and its standard error, coefficient of variation (CV) of the model (square root of variance of error as $\%$ of mean of dependent variable), BIC (Schwarz's Bayesian Information Criteria), significance level of the parameters estimated and $R^{2}$ values (as constructed from the generalised liner model). During preliminary analysis we observed that the use of weight statement for weighted regression analysis gave the same/similar estimates when weight statements were not used. This is probably because of similar variations across studies. Hence, in the final analysis we have not used weighted regression.

Presentation of results of mixed model regression in the form of a dependent versus predictor variable graph where the regression line is shown in conjunction with the observations need adjustment of observations for lost dimensions because observations come from a multidimensional space (multiple studies) to a two dimensional plane. Adjustment of DE intake in $\mathrm{kJ}$ per $\mathrm{kg}$ metabolic body size (DEIMBS) values were made by adding each mixed model derived residuals to its corresponding predicted DEIMBS values as suggested by St-Pierre (2001).

Feeding standards were derived for nutrient requirements of different nutrients for maintenance at different BWs and for gain in BW.

\section{Results}

General information about the feeding trials

In the database, average BW and ADG of experimental pigs ranged from 7.01 to $127.6 \mathrm{~kg}$ and 43 to $684 \mathrm{~g} /$ day, respectively (Table 2). The mean, s.e. and range of DE concentration $(\mathrm{MJ} / \mathrm{kg}), \mathrm{CP} \%$ and $\mathrm{CP}$ digestibility in the database were $12.6 \pm 0.09(9.64$ to $15.50 \mathrm{MJ} / \mathrm{kg})$, $17.4 \pm 0.16 \%(10.4$ to $24.0 \%)$ and $73.9 \pm 0.131 \%(52.4$ to $86.7 \%$ ), respectively. The range of each variable (Table 2 ) was sufficient for realistic regression analysis and is representative of diversities observed in animal and feeding situations in India.

\section{Energy and protein requirements}

The regression equations developed for the prediction of DE and CP requirements (Table 3$)$ had high $(P<0.001)$ significance level and $R^{2}$ values. The models had low variance of error estimates $\left(\sigma_{2}^{\text {error }}\right)$, standard errors, CV and $\mathrm{BIC}$. Comparison of actual versus predicted data indicated that presently derived requirements from the whole data set accurately predicted requirements of individual as well as group of pigs under varied dietary composition.

The estimated maintenance requirement of $D E$ was in the range of 516 to $702 \mathrm{~kJ} / \mathrm{kg} \mathrm{M}^{0.75}$ for different $B W$ ranges and the estimate from the whole database was $688 \mathrm{~kJ} / \mathrm{kg} \mathrm{M}^{0.75}$. The estimated requirements were in the range of 28.6 to 38.6 $\mathrm{kJ}$ DE per $\mathrm{g} A \mathrm{ADG}$ for different $\mathrm{BW}$ ranges and the 
Table 2 Mean values and variances of some of the variables analysed ${ }^{\dagger}$

\begin{tabular}{|c|c|c|c|c|c|c|c|c|c|c|c|c|c|c|c|c|c|c|}
\hline \multirow[b]{2}{*}{$\begin{array}{l}\text { BW range } \\
(\mathrm{kg})\end{array}$} & \multirow[b]{2}{*}{ No. } & & \multirow[b]{2}{*}{$\begin{array}{l}\text { Average } \\
\text { BW (kg) }\end{array}$} & \multirow[b]{2}{*}{$\begin{array}{l}\text { ADG } \\
(\mathrm{g})\end{array}$} & \multirow[b]{2}{*}{$\begin{array}{c}\text { DMI } \\
\text { (g/day) }\end{array}$} & \multirow[b]{2}{*}{$\begin{array}{c}D E \\
(\mathrm{~kJ} / \mathrm{kg})\end{array}$} & \multirow[b]{2}{*}{$\begin{array}{l}\mathrm{CP} \\
(\%)\end{array}$} & \multicolumn{11}{|c|}{ Amino acid } \\
\hline & & & & & & & & $\begin{array}{l}\text { Lys } \\
(\%)\end{array}$ & $\begin{array}{l}\text { Met } \\
(\%)\end{array}$ & $\begin{array}{l}\text { Cys } \\
(\%)\end{array}$ & $\begin{array}{c}\text { Met }+ \text { cys } \\
(\%)\end{array}$ & $\begin{array}{l}\text { Thr } \\
(\%)\end{array}$ & $\begin{array}{l}\operatorname{Arg} \\
(\%)\end{array}$ & $\begin{array}{l}\text { Tryp } \\
(\%)\end{array}$ & $\begin{array}{l}\text { Leu } \\
(\%)\end{array}$ & $\begin{array}{l}\text { Ile } \\
(\%)\end{array}$ & $\begin{array}{l}\text { Phe }+ \text { tyr } \\
(\%)\end{array}$ & $\begin{array}{l}\text { Val } \\
(\%)\end{array}$ \\
\hline \multirow[t]{4}{*}{$7-20$} & 36 & Min & 7.01 & 43 & 280 & 10284 & 12.1 & 0.37 & 0.08 & 0.12 & 0.49 & 0.38 & 0.41 & 0.12 & 0.66 & 0.35 & 0.65 & 0.48 \\
\hline & & Max & 19.5 & 591 & 2033 & 14644 & 21.8 & 0.89 & 0.64 & 0.44 & 0.91 & 0.61 & 1.25 & 0.25 & 1.82 & 0.79 & 1.46 & 0.88 \\
\hline & & Mean & 13.8 & 185 & 755 & 12146 & 19.7 & 0.76 & 0.37 & 0.26 & 0.63 & 0.54 & 0.92 & 0.17 & 1.50 & 0.64 & 1.20 & 0.74 \\
\hline & & s.e. & 0.65 & 22.9 & 72 & 212 & 0.39 & 0.03 & 0.03 & 0.01 & 0.03 & 0.02 & 0.08 & 0.01 & 0.12 & 0.04 & 0.08 & 0.04 \\
\hline \multirow[t]{4}{*}{$20-35$} & 83 & Min & 20.5 & 111 & 766 & 9636 & 12.8 & 0.49 & 0.21 & 0.16 & 0.44 & 0.38 & 0.57 & 0.12 & 0.98 & 0.46 & 0.93 & 0.59 \\
\hline & & Max & 34.7 & 548 & 3390 & 15489 & 24.0 & 0.90 & 0.83 & 0.35 & 1.15 & 0.74 & 1.82 & 0.30 & 1.98 & 0.96 & 1.83 & 1.12 \\
\hline & & Mean & 30.0 & 331 & 1392 & 12828 & 17.9 & 0.74 & 0.49 & 0.27 & 0.75 & 0.61 & 1.26 & 0.19 & 1.63 & 0.73 & 1.43 & 0.89 \\
\hline & & s.e. & 0.33 & 9.8 & 5419 & 170 & 0.25 & 0.01 & 0.02 & 0.01 & 0.03 & 0.01 & 0.04 & 0.01 & 0.03 & 0.01 & 0.03 & 0.02 \\
\hline \multirow[t]{4}{*}{$35-60$} & 101 & Min & 35.9 & 136 & 1090 & 9895 & 12.0 & 0.46 & 0.18 & 0.12 & 0.40 & 0.49 & 0.67 & 0.10 & 0.96 & 0.46 & 1.07 & 0.63 \\
\hline & & Max & 59.9 & 667 & 3190 & 15464 & 21.1 & 0.89 & 0.82 & 0.37 & 1.20 & 0.77 & 1.87 & 0.25 & 1.88 & 0.91 & 1.58 & 1.03 \\
\hline & & Mean & 47.2 & 375 & 1892 & 12485 & 16.9 & 0.76 & 0.42 & 0.24 & 0.66 & 0.62 & 1.24 & 0.17 & 1.62 & 0.71 & 1.34 & 0.84 \\
\hline & & s.e. & 0.66 & 10.2 & 44.7 & 156 & 0.22 & 0.01 & 0.02 & 0.01 & 0.03 & 0.01 & 0.05 & 0.01 & 0.03 & 0.02 & 0.03 & 0.02 \\
\hline \multirow[t]{4}{*}{$60-128$} & 35 & Min & 60.1 & 240 & 1668 & 11045 & 10.4 & 0.47 & 0.27 & 0.19 & 0.47 & 0.49 & 0.69 & 0.10 & 0.96 & 0.47 & 0.92 & 0.65 \\
\hline & & Max & 127.6 & 684 & 3467 & 14313 & 22.0 & 0.85 & 0.82 & 0.33 & 1.15 & 0.73 & 1.68 & 0.24 & 1.83 & 0.86 & 1.68 & 1.05 \\
\hline & & Mean & 66.9 & 468 & 2349 & 13100 & 15.0 & 0.63 & 0.55 & 0.27 & 0.82 & 0.56 & 1.02 & 0.16 & 1.49 & 0.62 & 1.24 & 0.78 \\
\hline & & s.e. & 1.87 & 20.6 & 71.7 & 177 & 0.56 & 0.03 & 0.03 & 0.01 & 0.02 & 0.04 & 0.01 & 0.06 & 0.01 & 0.02 & 0.03 & 0.02 \\
\hline \multirow[t]{4}{*}{ Overall } & 255 & Min & 7.01 & 43 & 280 & 9636 & 10.4 & 0.37 & 0.08 & 0.12 & 0.40 & 0.38 & 0.41 & 0.10 & 0.66 & 0.35 & 0.65 & 0.48 \\
\hline & & Max & 127.6 & 684 & 3467 & 15489 & 24.0 & 0.90 & 0.83 & 0.44 & 1.20 & 0.77 & 1.87 & 0.30 & 1.98 & 0.96 & 1.83 & 1.12 \\
\hline & & Mean & 39.4 & 346 & 1628 & 12631 & 17.4 & 0.74 & 0.45 & 0.26 & 0.71 & 0.59 & 1.18 & 0.18 & 1.58 & 0.69 & 1.34 & 0.84 \\
\hline & & s.e. & 1.05 & 8.64 & 40.7 & 92 & 0.16 & 0.01 & 0.013 & 0.004 & 0.01 & 0.007 & 0.027 & 0.04 & 0.02 & 0.01 & 0.018 & 0.01 \\
\hline
\end{tabular}

${ }^{\dagger}$ Abbreviations used: BW, body weight; ADG, average daily gain; DMI, dry matter intake; DE digestible energy; $C$, crude protein.

estimate from the whole database was $33.2 \mathrm{~kJ}$ DE per $\mathrm{g}$ ADG. The prediction equations accounted for 76 to $95 \%$ of the variations in observed DE intake. The distribution of adjusted DEIMBS and ADGMBS (ADG in $\mathrm{g} / \mathrm{kg}$ MBS) values in conjunction with mean regression line across studies has been depicted in Figure 1.Upon visual examination of Figure 1, there appeared a strong relationship between DEIMBS and ADGMBS $\left(R^{2}=0.76\right)$, and observations within study were very predictable. The prediction errors (CV) were in the range of 9.34 to $12.20 \%$ of actual mean intake and the overall prediction error of DE intake was in the order of
$9.61 \%$ of the actual mean intake, which indicated good accuracy of prediction across the database. The prediction equations were used for development of feeding standards for DE requirement (Table 5) based on average feed intake and growth rate observed in the database.

The maintenance requirements of $\mathrm{CP}$ ranged from 6.98 to $11.6 \mathrm{~g}$ per $\mathrm{kg} \mathrm{M}^{0.75}$ for different $\mathrm{BW}$ ranges, while the estimate from the whole database was $8.97 \mathrm{~g} \mathrm{CP}$ per $\mathrm{kg}$ $\mathrm{M}^{0.75}$. The estimated requirements were in the range of 0.27 to $0.44 \mathrm{~g} \mathrm{CP}$ per $\mathrm{g}$ ADG for different BW ranges and the estimate from the whole database was $0.42 \mathrm{~g}$

Table 3 Parameter estimates obtained using regression model ${ }^{\dagger}$ for apportioning of energy $(\mathrm{kJ})$ and protein $(\mathrm{g})$ intake for maintenance (a) per kg $M^{0.75}$ and growth per g gain) $(b)^{\ddagger}$

\begin{tabular}{|c|c|c|c|c|c|c|c|c|}
\hline BW range $(\mathrm{kg})$ & No. of observations & Nutrient & $a$ & $b$ & $\sigma_{2}^{\text {error }}$ & $\mathrm{BIC}$ & $R^{2 \S}$ & CV $(\%)$ \\
\hline \multirow[t]{2}{*}{$7-20$} & 36 & $\mathrm{DE}(\mathrm{kJ})$ & $532 \pm 64$ & $32 \pm 4.81$ & $23195 \pm 5121$ & 375.3 & 0.944 & 11.89 \\
\hline & & $C P(g)$ & $11.62 \pm 2.22$ & $0.39 \pm 0.09$ & $4.22 \pm 1.15$ & 179.9 & 0.861 & 11.49 \\
\hline \multirow[t]{2}{*}{$20-35$} & 83 & $\mathrm{DE}(\mathrm{kJ})$ & $516 \pm 85$ & $34 \pm 6.86$ & $25655 \pm 4358$ & 709.3 & 0.954 & 9.34 \\
\hline & & $C P(g)$ & $11.52 \pm 2.0$ & $0.31 \pm 0.04$ & $4.23 \pm 0.72$ & 445.2 & 0.926 & 10.76 \\
\hline \multirow[t]{2}{*}{$35-60$} & 101 & $\mathrm{DE}(\mathrm{kJ})$ & $702 \pm 87$ & $28.6 \pm 3.9$ & $25620 \pm 4229$ & 866.2 & 0.823 & 12.20 \\
\hline & & $C P(g)$ & $10.68 \pm 4.58$ & $0.27 \pm 0.14$ & $6.88 \pm 1.07$ & 531.6 & 0.670 & 14.89 \\
\hline \multirow[t]{2}{*}{$60-128$} & 35 & $D E(k J)$ & $564 \pm 124$ & $38.6 \pm 6.52$ & $21360 \pm 6259$ & 364.9 & 0.811 & 11.11 \\
\hline & & $\mathrm{CP}(\mathrm{g})$ & $6.98 \pm 3.16$ & $0.44 \pm 0.14$ & $3.97 \pm 1.20$ & 187.2 & 0.896 & 13.03 \\
\hline \multirow[t]{2}{*}{ Overall (7-128) } & 255 & $\mathrm{DE}(\mathrm{kJ})$ & $688 \pm 40$ & $33 \pm 3.6$ & $15790 \pm 1489$ & 2712 & 0.760 & 9.61 \\
\hline & & $\mathrm{CP}(\mathrm{g})$ & $8.97 \pm 1.37$ & $0.42 \pm 0.05$ & $3.99 \pm 0.39$ & 1240.2 & 0.790 & 11.13 \\
\hline
\end{tabular}

\footnotetext{
${ }^{\dagger}$ Model: intake/MBW $=a+b(\mathrm{ADG} / \mathrm{MBW})$; analysed using mixed model method considering study effect and its interaction effects as random. (Each observation is mean of observations on at least four animals.)

${ }^{\ddagger}$ Abbreviations used: BW, body weight; DE, digestible energy; $C$, crude protein; BIC, Schwarz's Bayesian Information Criteria; $\sigma_{2}^{\text {error }}=$ variance of error estimate.

${ }^{\S}$ Coefficient of determination constructed for the mixed effects model.
} 


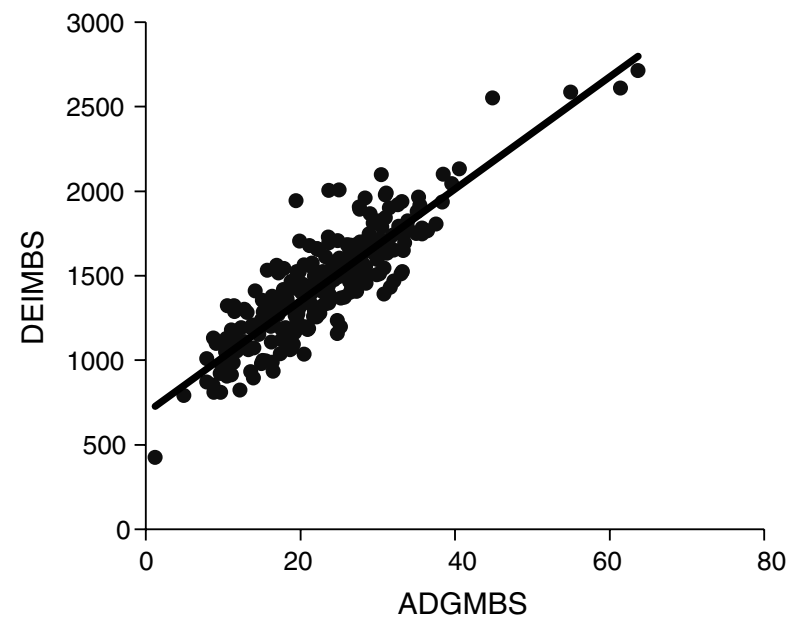

Figure 1 Plot of adjusted digestible energy intake in $\mathrm{kJ}$ per kg metabolic body size (DEIMBS) on average daily gain in $\mathrm{g}$ per $\mathrm{kg}$ metabolic body size (ADGMBS) and the mean regression line across studies $\left(y=33.144 x+688.07 ; R^{2}=0.7617\right)$.

CP per $g$ ADG. The prediction equations accounted for 67 to $93 \%$ of the variations in observed CP intake. The distribution of adjusted DEIMBS and ADGMBS values in conjunction with mean regression line across studies has been depicted in Figure 2. A strong relationship existed (Figure 2) between CPIMBS and ADGMBS $\left(R^{2}=0.79\right)$, and observations within study are highly predictable. The prediction errors (CV) were in the range of 10.76 to $14.89 \%$ of actual mean intake and the overall prediction error of $\mathrm{CP}$ intake were of the order of $11.13 \%$ of the actual mean intake, which indicated good accuracy of prediction across the database. The prediction equations were used for development of feeding standards for CP requirement (Table 5) based on average feed intake and growth rate observed in the database.

\section{Amino acid requirements}

The regression equations developed for the prediction of amino acid requirements (Table 4$)$ had high $(P<0.001)$ significance level of the parameters estimated and high $R^{2}$ values. The models had low variance of error estimates $\left(\sigma_{2}^{\text {error}}\right)$ and their standard errors, low CV and low BIC.

The estimated maintenance requirements of lysine were in the range of 0.431 to $0.664 \mathrm{~g}$ per $\mathrm{kg} \mathrm{M}^{0.75}$ for different BW ranges and the estimate from the whole database was $0.394 \mathrm{~g}$ per $\mathrm{kg} \mathrm{M}^{0.75}$. The estimated requirements for gains were in the range of 0.0071 to $0.0101 \mathrm{~g}$ per $\mathrm{g} \mathrm{ADG}$ for different $B W$ ranges and the estimate from the whole database was $0.01257 \mathrm{~g}$ lysine per $\mathrm{g} \mathrm{ADG}$.

The estimated methionine requirements ranged from 0.265 to $0.458 \mathrm{~g}$ per $\mathrm{kg} \mathrm{M}^{0.75}$ for different $\mathrm{BW}$ ranges. The estimated values for gain were 0.0065 to $0.0124 \mathrm{~g}$ per $\mathrm{g}$ $A D G$ for different $B W$ ranges.

The estimated maintenance requirements of methionine + cystine were 0.327 to $0.466 \mathrm{~g}$ per $\mathrm{kg} \mathrm{M}^{0.75}$ for different BWs. The estimated requirements for live-weight gains were 0.0151 to $0.0261 \mathrm{~g} / \mathrm{g} \mathrm{ADG}$ for different BW ranges.

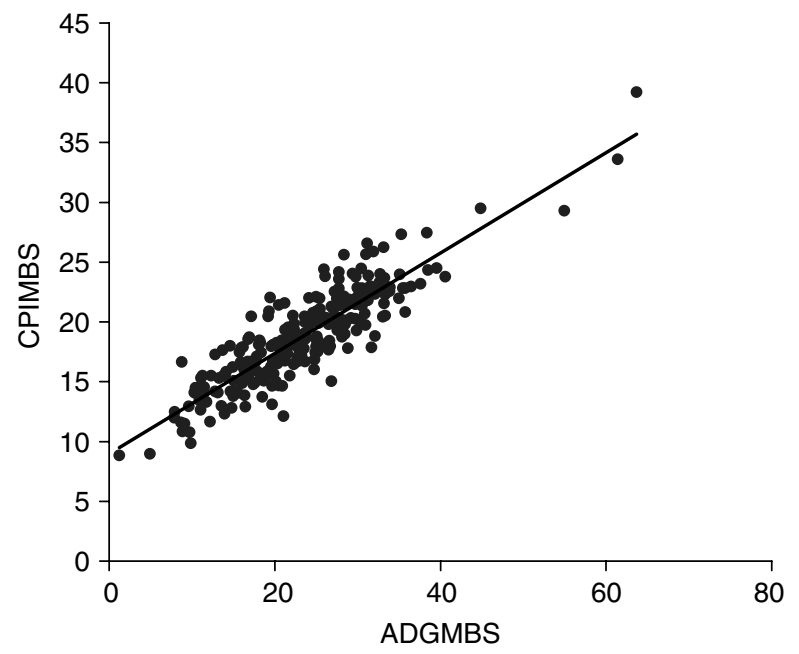

Figure 2 Plot of adjusted crude protein intake in $\mathrm{g}$ per $\mathrm{kg}$ metabolic body size (CPIMBS) on average daily gain in $\mathrm{g}$ per $\mathrm{kg}$ metabolic body size (ADGMBS) and the mean regression line across studies $\left(y=0.42 x+8.9707 ; R^{2}=0.7902\right)$.

Cystine requirements were estimated for maintenance as 0.055 to $0.184 \mathrm{~g}$ per $\mathrm{kg} \mathrm{M}^{0.75}$ for different BW ranges. The requirements were in the range of 0.0043 to $0.0094 \mathrm{~g}$ per $g$ ADG for different BW ranges.

Threonine requirements for maintenance were estimated as 0.205 to $0.511 \mathrm{~g}$ per $\mathrm{kg} \mathrm{M}^{0.75}$ for different BW ranges. The values of threonine requirements for live-weight gains were 0.0052 to $0.0165 \mathrm{~g}$ per $\mathrm{g}$ ADG for different $\mathrm{BW}$ ranges.

The estimated arginine requirements for maintenance ranged from 0.377 to $1.21 \mathrm{~g}$ per $\mathrm{kg} \mathrm{M}^{0.75}$ for different $\mathrm{BW}$ range. The estimated requirements for gain were in the range of 0.0045 to $0.0301 \mathrm{~g}$ arginine per $\mathrm{g}$ ADG for different BW ranges.

The estimated isoleucine requirements for maintenance were 0.241 to $0.775 \mathrm{~g}$ per $\mathrm{kg} \mathrm{M} \mathrm{M}^{0.75}$ for different $\mathrm{BW}$ ranges. The requirements for gains ranged from 0.0023 to $0.0198 \mathrm{~g}$ per $\mathrm{g} A D G$ for different $\mathrm{BW}$ ranges.

The estimated maintenance requirements of leucine were in the range of 0.604 to $1.54 \mathrm{~g}$ per $\mathrm{kg} \mathrm{M}^{0.75}$ for different BW ranges. The estimated requirements for liveweight gains were in the range of 0.0150 to $0.0447 \mathrm{~g}$ per $g$ ADG for different BW ranges.

The phenylalanine + tyrosine requirements for maintenance were 0.496 to $1.33 \mathrm{~g}$ per $\mathrm{kg} \mathrm{M}^{0.75}$ for different BW ranges. For live-weight gains, the values emerged as 0.0091 to $0.0382 \mathrm{~g}$ per $\mathrm{g}$ ADG for different BW ranges.

The maintenance requirements of tryptophan were predicted as 0.078 to $0.213 \mathrm{~g}$ per $\mathrm{kg} \mathrm{M}^{0.75}$ for different $\mathrm{BW}$ ranges. Those for gains were 0.0005 to $0.0044 \mathrm{~g}$ per $\mathrm{g}$ $A D G$ for different $B W$ ranges.

Valine requirements were estimated 0.330 to $0.892 \mathrm{~g}$ per $\mathrm{kg} \mathrm{M}^{0.75}$ for different $\mathrm{BW}$ ranges. The values for gains were 0.0061 to $0.0222 \mathrm{~g}$ per $\mathrm{g}$ ADG for different $\mathrm{BW}$ ranges.

The prediction equations were used for development of feeding standards for amino acid requirements and 
Table 4 Parameter estimates obtained using regression model ${ }^{\dagger}$ for partitioning of amino acid intakes for maintenance $\left(a, g\right.$ per $\left.\mathrm{kg} \mathrm{M}^{0.75}\right)$ and growth (b, g/g gain)

\begin{tabular}{|c|c|c|c|c|c|c|c|}
\hline $\mathrm{BW}$ range $(\mathrm{kg})$ & Nutrient & $a$ & $b$ & $\sigma_{\text {error }}^{2}$ & $\mathrm{BIC}$ & $R^{2 \S}$ & CV (\%) \\
\hline \multirow[t]{11}{*}{$7-20$} & Lysine & $0.568 \pm 0.057$ & $0.0071 \pm 0.0024$ & $0.00987 \pm 0.00312$ & -16.80 & 0.829 & 13.52 \\
\hline & Methionine & $0.265 \pm 0.032$ & $0.0124 \pm 0.0047$ & $0.00359 \pm 0.00114$ & -29.33 & 0.956 & 15.26 \\
\hline & Methionine + cystine & $0.392 \pm 0.037$ & $0.0188 \pm 0.0053$ & $0.00467 \pm 0.00148$ & -22.76 & 0.969 & 10.31 \\
\hline & Cystine & $0.128 \pm 0.038$ & $0.0066 \pm 0.0010$ & $0.00350 \pm 0.00112$ & -46.05 & 0.859 & 21.86 \\
\hline & Threonine & $0.205 \pm 0.065$ & $0.0165 \pm 0.0014$ & $0.00383 \pm 0.00267$ & 2.95 & 0.992 & 8.14 \\
\hline & Arginine & $0.377 \pm 0.087$ & $0.0301 \pm 0.0047$ & $0.08632 \pm 0.05788$ & 18.14 & 0.982 & 21.61 \\
\hline & Isoleucine & $0.241 \pm 0.081$ & $0.0198 \pm 0.0031$ & $0.00955 \pm 0.00600$ & 10.82 & 0.972 & 10.78 \\
\hline & Leucine & $0.862 \pm 0.159$ & $0.0366 \pm 0.0106$ & $0.01614 \pm 0.01214$ & 14.3 & 0.996 & 5.71 \\
\hline & Phenylalanine + tyrosine & $0.496 \pm 0.113$ & $0.0382 \pm 0.0029$ & $0.03261 \pm 0.01962$ & 15.69 & 0.991 & 10.35 \\
\hline & Tryptophan & $0.104 \pm 0.041$ & $0.0034 \pm 0.0012$ & $0.00108 \pm 0.00063$ & -2.07 & 0.857 & 15.12 \\
\hline & Valine & $0.330 \pm 0.072$ & $0.0222 \pm 0.0018$ & $0.01320 \pm 0.00769$ & 11.26 & 0.990 & 10.87 \\
\hline \multirow[t]{11}{*}{$20-35$} & Lysine & $0.567 \pm 0.055$ & $0.0101 \pm 0.0017$ & $0.00338 \pm 0.00083$ & -69.81 & 0.808 & 7.47 \\
\hline & Methionine & $0.327 \pm 0.076$ & $0.0077 \pm 0.0023$ & $0.00251 \pm 0.00084$ & -42.15 & 0.960 & 10.35 \\
\hline & Methionine + cystine & $0.455 \pm 0.082$ & $0.0151 \pm 0.0030$ & $0.00373 \pm 0.00104$ & -50.1 & 0.952 & 8.11 \\
\hline & Cystine & $0.184 \pm 0.024$ & $0.0043 \pm 0.0007$ & $0.00058 \pm 0.00013$ & -194.32 & 0.922 & 8.44 \\
\hline & Arginine & $0.568 \pm 0.211$ & $0.0279 \pm 0.0069$ & $0.01981 \pm 0.00706$ & 6.99 & 0.863 & 10.91 \\
\hline & Threonine & $0.302 \pm 0.085$ & $0.0132 \pm 0.0029$ & $0.00349 \pm 0.00098$ & -60.18 & 0.899 & 9.52 \\
\hline & Isoleucine & $0.416 \pm 0.123$ & $0.0131 \pm 0.0038$ & $0.00539 \pm 0.00166$ & -26.9 & 0.829 & 9.72 \\
\hline & Leucine & $0.929 \pm 0.136$ & $0.0299 \pm 0.0054$ & $0.01577 \pm 0.00454$ & -.0175 & 0.870 & 5.64 \\
\hline & Phenylalanine + tyrosine & $0.689 \pm 0.170$ & $0.0301 \pm 0.0060$ & $0.02479 \pm 0.00662$ & 1.997 & 0.811 & 10.77 \\
\hline & Tryptophan & $0.078 \pm 0.029$ & $0.0044 \pm 0.0010$ & $0.00052 \pm 0.00017$ & -110.9 & 0.988 & 12.00 \\
\hline & Valine & $0.368 \pm 0.119$ & $0.0205 \pm 0.0040$ & $0.01037 \pm 0.00331$ & -21.9 & 0.838 & 11.27 \\
\hline \multirow[t]{11}{*}{$35-60$} & Lysine & $0.664 \pm 0.056$ & $0.0075 \pm 0.0021$ & $0.00637 \pm 0.00119$ & -100.17 & 0.501 & 10.19 \\
\hline & Methionine & $0.438 \pm 0.089$ & $0.0047 \pm 0.0014$ & $0.00159 \pm 0.00033$ & -141.49 & 0.501 & 10.19 \\
\hline & Methionine + cystine & $0.466 \pm 0.089$ & $0.0161 \pm 0.0027$ & $0.00541 \pm 0.00110$ & -93.82 & 0.968 & 11.83 \\
\hline & Cystine & $0.055 \pm 0.023$ & $0.0094 \pm 0.0013$ & $0.00099 \pm 0.00017$ & -228.82 & 0.953 & 11.28 \\
\hline & Threonine & $0.511 \pm 0.052$ & $0.0052 \pm 0.0018$ & $0.00232 \pm 0.00095$ & -37.9 & 0.857 & 13.45 \\
\hline & Arginine & $1.21 \pm 0.129$ & $0.0045 \pm 0.0017$ & $0.01301 \pm 0.00550$ & -4.18 & 0.589 & 8.55 \\
\hline & Isoleucine & $0.775 \pm 0.046$ & $0.0023 \pm 0.0017$ & $0.00435 \pm 0.00138$ & -10.16 & 0.758 & 7.89 \\
\hline & Leucine & $1.54 \pm 0.240$ & $0.0150 \pm 0.0084$ & $0.02793 \pm 0.00974$ & 10.79 & 0.758 & 8.50 \\
\hline & Phenylalanine + tyrosine & $1.33 \pm 0.243$ & $0.0091 \pm 0.0014$ & $0.01570 \pm 0.0052$ & 2.265 & 0.695 & 7.66 \\
\hline & Tryptophan & $0.213 \pm 0.017$ & $0.0005 \pm 0.00006$ & $0.00048 \pm 0.00019$ & -64.49 & 0.650 & 9.71 \\
\hline & Valine & $0.892 \pm 0.170$ & $0.0061 \pm 0.0039$ & $0.00734 \pm 0.00252$ & -21.72 & 0.769 & 7.63 \\
\hline \multirow[t]{11}{*}{$60-128$} & Lysine & $0.431 \pm 0.117$ & $0.0096 \pm 0.0053$ & $0.00799 \pm 0.00319$ & -14.03 & 0.828 & 13.88 \\
\hline & Methionine & $0.458 \pm 0.089$ & $0.0065 \pm 0.0025$ & $0.00784 \pm 0.00460$ & -11.87 & 0.836 & 14.66 \\
\hline & Methionine + cystine & $0.327 \pm 0.159$ & $0.026 \pm 0.0070$ & $0.00992 \pm 0.00373$ & -4.27 & 0.928 & 11.88 \\
\hline & Cystine & $0.148 \pm 0.055$ & $0.0065 \pm 0.0025$ & $0.00075 \pm 0.00028$ & -48.9 & 0.883 & 9.99 \\
\hline & Threonine & $0.326 \pm 0.088$ & $0.0120 \pm 0.0039$ & $0.00482 \pm 0.00201$ & -23.38 & 0.845 & 11.94 \\
\hline & Arginine & $0.896 \pm 0.463$ & $0.0065 \pm 0.0174$ & $0.00443 \pm 0.0 .00193$ & 26.58 & 0.856 & 19.77 \\
\hline & Isoleucine & $0.406 \pm 0.090$ & $0.0115 \pm 0.0040$ & $0.01060 \pm 0.0037$ & -1.69 & 0.780 & 15.87 \\
\hline & Leucine & $0.604 \pm 0.154$ & $0.0447 \pm 0.0069$ & $0.04225 \pm 0.014900$ & 15.38 & 0.781 & 13.19 \\
\hline & Phenylalanine + tyrosine & $0.496 \pm 0.113$ & $0.0382 \pm 0.0028$ & $0.03261 \pm 0.01962$ & 15.69 & 0.991 & 10.34 \\
\hline & Tryptophan & $0.110 \pm 0.033$ & $0.0026 \pm 0.0017$ & $0.00099 \pm 0.00032$ & -39.7 & 0.837 & 19.26 \\
\hline & Valine & $0.653 \pm 0.245$ & $0.0074 \pm 0.0019$ & $0.001158 \pm 0.00500$ & 0.492 & 0.852 & 13.27 \\
\hline \multirow[t]{11}{*}{ Overall (7-128) } & Lysine & $0.394 \pm 0.0517$ & $0.0126 \pm 0.0013$ & $0.00647 \pm 0.000783$ & -285.7 & 0.703 & 10.67 \\
\hline & Methionine & $0.266 \pm 0.0277$ & $0.0133 \pm 0.00173$ & $0.00239 \pm 0.000339$ & -295.0 & 0.947 & 11.69 \\
\hline & Methionine + cystine & $0.366 \pm 0.0244$ & $0.02244 \pm 0.00224$ & $0.0058 \pm 0.000721$ & -234.7 & 0.926 & 10.68 \\
\hline & Cystine & $0.129 \pm 0.009$ & $0.0067 \pm 0.00054$ & $0.001526 \pm 0.00018$ & -580.28 & 0.838 & 14.97 \\
\hline & Threonine & $0.321 \pm 0.0222$ & $0.0126 \pm 0.00088$ & $0.003389 \pm 0.000505$ & -100.05 & 0.915 & 13.15 \\
\hline & Arginine & $0.531 \pm 0.1032$ & $0.0290 \pm 0.0028$ & $0.0286 \pm 0.00528$ & 12.67 & 0.842 & 13.53 \\
\hline & Isoleucine & $0.401 \pm 0.0707$ & $0.01418 \pm 0.0022$ & $0.00628 \pm 0.001104$ & -126.48 & 0.862 & 10.33 \\
\hline & Leucine & $0.903 \pm 0.0798$ & $0.03365 \pm 0.00376$ & $0.02797 \pm 0.004987$ & 7.32 & 0.913 & 9.32 \\
\hline & Phenylalanine + tyrosine & $0.662 \pm 0.0777$ & $0.0345 \pm 0.00371$ & $0.02545 \pm 0.00409$ & -0.329 & 0.874 & 10.59 \\
\hline & Tryptophan & $0.117 \pm 0.022$ & $0.00310 \pm 0.00074$ & $0.000656 \pm 0.00012$ & -280.25 & 0.831 & 9.71 \\
\hline & Valine & $0.424 \pm 0.062$ & $0.0208 \pm 0.0020$ & $0.00956 \pm 0.00001$ & -88.01 & 0.881 & 10.44 \\
\hline
\end{tabular}

\footnotetext{
${ }^{\dagger}$ Model: intake/MBW $=a+b(\mathrm{ADG} / \mathrm{MBW})$; analysed using mixed model method considering study effect and its interaction effects as random. (Each observation is mean of observations on at least four animals.)

${ }^{\ddagger}$ Abbreviations used: BW, body weight; BIC, Schwarz's Bayesian Information Criteria; $\sigma_{2}^{\text {error }}=$ variance of error estimate.

${ }^{\S}$ Coefficient of determination constructed for the mixed effects model.
} 
Paul, Mandal, Chatterjee, Bhar and Pathak

Table 5 Daily nutrient requirements of growing pigs allowed feed ad libitum ${ }^{\dagger}$

\begin{tabular}{|c|c|c|c|c|c|c|c|c|}
\hline & \multicolumn{4}{|c|}{ Body weight $(\mathrm{kg})$} & & & & \\
\hline & $7-20$ & $20-35$ & $35-60$ & $60-127$ & & & & \\
\hline Average weight in the range $(\mathrm{kg})$ & 13.8 & 30.0 & 47.2 & 66.9 & & & & \\
\hline ADG (g/day) & 185 & 331 & 375 & 468 & & & & \\
\hline Average feed intake (DM, g/day) & 755 & 1392 & 1892 & 2349 & & & & \\
\hline Estimated DE requirement ( $\mathrm{JJ} /$ day) & 2330 & 4296 & 5572 & 7475 & & & & \\
\hline \multirow[t]{3}{*}{ Estimated CP requirement (g/day) } & 155 & 250 & 294 & 369 & & & & \\
\hline & \multicolumn{8}{|c|}{ Estimated amino acid (total basis) requirements } \\
\hline & g/day & $\%$ of lys & g/day & $\%$ of lys & g/day & $\%$ of lys & g/day & $\%$ of lys \\
\hline Lysine & 5.37 & 100 & 10.61 & 100 & 14.76 & 100 & 14.57 & 100 \\
\hline Methionine & 4.18 & 78 & 6.72 & 63 & 9.64 & 65 & 13.75 & 94 \\
\hline Methionine + cystine & 6.28 & 117 & 8.63 & 81 & 14.43 & 98 & 19.82 & 136 \\
\hline Cystine & 2.13 & 40 & 3.78 & 36 & 4.50 & 31 & 6.50 & 45 \\
\hline Threonine & 4.52 & 84 & 8.24 & 78 & 11.15 & 76 & 13.24 & 91 \\
\hline Arginine & 8.24 & 153 & 16.53 & 156 & 23.47 & 159 & 24.00 & 165 \\
\hline Isoleucine & 5.38 & 100 & 9.66 & 91 & 14.82 & 100 & 14.87 & 102 \\
\hline Leucine & 12.94 & 240 & 21.80 & 205 & 33.35 & 226 & 35.04 & 240 \\
\hline Phenylalanine + tyrosine & 10.62 & 198 & 18.79 & 177 & 27.36 & 185 & 29.48 & 202 \\
\hline Tryptophan & 1.36 & 25 & 2.45 & 23 & 4.03 & 27 & 3.78 & 26 \\
\hline Valine & 6.46 & 120 & 11.50 & 108 & 18.35 & 124 & 18.73 & 60 \\
\hline
\end{tabular}

${ }^{+}$Abbreviations used: $A D G$, average daily gain; $D M$, dry matter; $D E$, digestible energy; $C P$, crude protein.

required dietary concentration of amino acids were worked out for growing pigs with expected BW, feed intake and growth rate similar to those of the average values observed in the database (Table 5).

\section{Discussion}

The estimated DE requirements for maintenance at different BWs (516 to $702 \mathrm{~kJ} / \mathrm{kg} \mathrm{M}^{0.75}$ ) are higher than the value $\left(460 \mathrm{~kJ} / \mathrm{kg} \mathrm{M}^{0.75}\right)$ adopted in the feeding standards of NRC (1998). The estimates of DE requirements for maintenance of pigs as reported in the literature across the world vary from 402 to $699 \mathrm{~kJ} / \mathrm{kg} \mathrm{M}^{0.75}$ with most of the values falling between 435 to $544 \mathrm{~kJ} / \mathrm{kg} \mathrm{M}^{0.75}$ (Whittemore, 1976; Bohme et al., 1980; Wenk et al., 1980; Agricultural Research Council, 1981; Noblet and Le Dividich, 1982; Campbell and Dunkin, 1983; Close and Stanier, 1984; McNutt and Ewan, 1984; Gadeken et al., 1985; Noblet et al., 1985). Hence, estimates of maintenance requirements obtained in the present study were in general agreement with previous reports. The estimated DE requirements for maintenance at 60 to $128 \mathrm{~kg}$ were lower than the values at 35 to $60 \mathrm{~kg} \mathrm{BW}$. This is probably because of the fact that at higher $(>50 \mathrm{~kg}) \mathrm{BWs}$ inherited upper limit of protein retention of individual pig determines response of energy on growth rather than the amount of energy intake as observed in lower BWs (Schinchel and De Lange, 1996). Hence at higher BWs standard error of estimated parameter increases and predictability reduces. However, the estimate is within range of values reported for pigs of such weight range.
The energy requirements in the present study were estimated to be 32, 34.3, 28.6 and 38.6 kJ DE per g ADG for 7 to 20,20 to 35,35 to 60 and 60 to $128 \mathrm{~kg} \mathrm{BW}$, respectively (Table 3 ). No report on energy requirement of Indian pigs for growth could be traced hence direct comparison is not possible, however the values are slightly higher than the values reported for Indian sheep (Paul et al., 2003b) and goats (Mandal et al., 2005). Higher requirements of energy for gain at finishing stage is probably due to accumulation of more body fat over muscle tissue. NRC (1998) has also reported higher values for finishing period.

The estimates of requirement of $\mathrm{CP}$ for maintenance emanated from present database were 11.62, 11.52, 10.68 and $6.98 \mathrm{~g} / \mathrm{kg} \mathrm{M}^{0.75}$ for the corresponding BWs. The CP requirements for $1 \mathrm{~g}$ ADG were estimated to be $0.39,0.31$, 0.27 and $0.44 \mathrm{~g}$ in the present study (Table 3).

Reports on partitioning of nutrient requirements for maintenance and growth of Indian pigs are scanty because most of the workers estimated requirements for maintenance and production together and expressed requirements in term of dietary concentration of nutrients. The existing Indian feeding standards (ICAR, 1998) do not give separate requirements for maintenance and gain but rather give total requirements. Most of the Indian workers fed pigs on a range of diets varying in energy and protein content, and the energy or protein level supporting highest growth rate and feed conversion efficiency was considered to be optimum requirements.

The estimates of dietary requirement of total energy for maintenance and growth emanated from present database 
were 12.91, 12.91, 12.32 and 13.31 MJ DE per kg diet for 7 to 20,20 to 35,35 to 60 and 60 to $127 \mathrm{~kg} \mathrm{BW}$, respectively. The estimates are in agreement with the report of Dhudapker et al. (1971) who reported that growing Middle White Yorkshire pigs require $12.76 \mathrm{MJ}$ DE per $\mathrm{kg}$ diet under Indian condition. Our estimates differ substantially from the values of energy requirement suggested by ICAR (1998): $13.81,12.43,11.04$ and $11.04 \mathrm{MJ} / \mathrm{kg} \mathrm{DE}$ for 10 to 20,20 to 30,35 to 60 and 60 to $90 \mathrm{~kg} \mathrm{BW}$, respectively. Our estimates also differ substantially from those of Sharda and Sagar (1986) who reported that Middle White Yorkshire pigs require $14.64 \mathrm{MJ} \mathrm{DE}$ per $\mathrm{kg}$ diet, $12.43 \mathrm{MJ} \mathrm{DE}$ per $\mathrm{kg}$ diet, $11.04 \mathrm{MJ} \mathrm{DE}$ per $\mathrm{kg}$ diet and $11.04 \mathrm{MJ} \mathrm{DE} / \mathrm{kg}$ diet from 10 to $20 \mathrm{~kg}, 20$ to $35 \mathrm{~kg}, 35$ to $60 \mathrm{~kg}$ and 60 to $75 \mathrm{~kg}$, respectively under Indian condition. Reddy et al. (1981) reported that Large White Yorkshire pigs weighing 20 to $35 \mathrm{~kg}$ under Indian conditions require $13.80 \mathrm{MJ} D$ per $\mathrm{kg}$ diet. Present estimates are lower than the requirement of $14.22 \mathrm{MJ}$ DE per $\mathrm{kg}$ diet recommended by NRC (1998) for growing pigs irrespective of BWs.

The estimates of dietary requirement of total CP for maintenance and growth emanated from present database were $20.6,18.0,15.5$ and $15.7 \%$ in diet for 7 to 20,20 to 35,35 to 60 and 60 to $127 \mathrm{~kg} \mathrm{BW}$, respectively. Our estimates are higher than the values recommended by ICAR (1998) feeding standards: 18, 15, 13 and 12\% CP for 10 to $20 \mathrm{~kg}, 20$ to $35 \mathrm{~kg}, 35$ to $60 \mathrm{~kg}$ and 60 to $75 \mathrm{~kg}$, respectively. Earlier, Sharda and Sagar (1986) reported that Middle White Yorkshire pigs require 18.0, 14.4, 11.2 and 10.8\% CP in diet for 10 to $20 \mathrm{~kg}, 20$ to $35 \mathrm{~kg}, 35$ to $60 \mathrm{~kg}$ and 60 to $75 \mathrm{~kg}$, respectively. Dhudapker et al. (1971) reported that growing Middle White Yorkshire pigs require 18\% CP in diet. Reddy et al. (1982) reported that Large White Yorkshire pigs weighing 20 to $35 \mathrm{~kg}$ under Indian conditions require 18\% CP. Sharda et al. (1982a) reported that crossbred pigs (Middle White Yorkshire $\times$ Indian nondescript) between 14 and $52 \mathrm{~kg}$ BW require $16 \%$ CP in growing phase (14 to $25 \mathrm{~kg} \mathrm{BW}$ ) and $14 \%$ in finishing phase (25 to $71 \mathrm{~kg} \mathrm{BW}$ ) for optimum growth and feed efficiency but for producing leaner carcasses pigs needed $18 \%$ $\mathrm{CP}$ in growing phase and $16 \% \mathrm{CP}$ in finishing phase. Present estimates are slightly higher than these reports. However, present estimates are comparable with the values recommended by NRC (1998) feeding standards: 20.9, 18, 15.5 and $13.2 \%$ CP for 10 to 20,20 to 50,50 to 80 and 80 to $120 \mathrm{~kg} \mathrm{BWs}$, respectively.

Information on amino acid requirements of Indian pigs is scanty. ICAR (1998) standards did not give requirements for amino acids. Sharda et al. (1982a) observed that ADG of pigs fed $18 \%$ CP (with $0.71 \%$ lysine) and $16 \%$ CP (with $0.63 \%$ lysine) was similar but higher than those fed $14 \%$ $\mathrm{CP}$ with $0.54 \%$ lysine indicating that lysine requirement during growth phase may be $0.63 \%$. Present estimates of dietary lysine requirement if expressed as \% in diet are slightly higher than this report. Apportioning of lysine requirement for maintenance and growth indicated that maintenance requirements range from 0.431 to $0.664 \mathrm{~g} / \mathrm{kg}$
$\mathrm{M}^{0.75}$ and growth requirements range from 0.0071 to $0.0101 \mathrm{~g} / \mathrm{g} \mathrm{ADG}$. Our estimate of Lys requirements for maintenance is higher than the value reported by Fuller et al. (1989) of $0.036 \mathrm{~g}$ per $\mathrm{kg} \mathrm{M}^{0.75}$. This difference can probably be attributed to following facts. Amino acid requirements are known to be dependent on genotype (e.g. animal's inherited upper limit to protein retention), environmental condition (stressors limit response to dietary nutrients), gastro-intestinal (GI) health (degree of sloughing of GI tract mucosa), and dietary situation (content of other amino acids, non-protein $\mathrm{N}$, energy, interaction of energy and amino acids, fibre, digestibility of amino acids, etc.) and nutritional history of the animal. More importantly, methodological differences could be an important source of variance. Fuller et al. (1989) have estimated amino acid requirements based on $\mathrm{N}$ balance on metabolism trial employing graded amino acid levels and protein (at near or below maintenance level of $\mathrm{N}$ in the diet employing deletion method) in the synthetic (fibre-free) diet and $\mathrm{N}$ balance was used as response criteria. The amounts of amino acid needed to maintain the animal in $\mathrm{N}$ equilibrium were taken as maintenance requirement. The difficulty with this concept is that adult animals can adjust $\mathrm{N}$ output and reach equilibrium, particularly at lower levels of N/amino acid intake. Thus, $\mathrm{N}$ equilibrium as an indicator of adequate protein/amino acid intake is of questionable value (NRC, 1981). As endogenous secretions of amino acids rise with increase in dietary fibre and protein, measurements of maintenance requirements with synthetic or depleted diets are likely to be lower than those obtained with high fibrous or normal practical diets (Whittemore et al., 2001). The estimate of Fuller et al. (1989) indicate theoretical minimum requirement for maintenance of $\mathrm{N}$ equilibrium under hypothetical situation i.e. when the animal is not gaining/loosing weight. Optimum nutrition of maintaining producing animals calls for a higher intake than the minimum required for maintaining $\mathrm{N}$ equilibrium as producing animals maintained under farm condition have more intense metabolism and protein turnover, than those under balance trial or under maintenance plane of nutrition (McDonald et al., 1995). Thus, the maintenance requirements as estimated in our study by regression of growth $v$. $B W$ and $A D G$ data (using weight gain as response criteria instead of $\mathrm{N}$ balance) in producing animals maintained under farm condition (high environmental stress) and practical diet (high fibre/protein diet and diets containing unconventional feeds/agro industrial by products) is expected to be higher than the estimate derived by Fuller et al. (1989). Information on partitioning of lysine requirements of growing pigs for maintenance and growth are scanty. Most of the studies on nutrient requirements of growing pigs have studies combined requirements for maintenance and growth and studied optimum dietary level of lysine for optimum growth. Yang et al. (1997a) on regression analysis of intake $v$. growth in feeding trial, reported that growing pigs require upto $0.115 \mathrm{~g}$ lys per $\mathrm{kg}$ $M^{0.75}$ for maintenance which is also much higher than the 
report of Fuller et al. (1989) but lower than our estimates. No report on lysine requirements for maintenance of growing pigs under Indian condition is available for comparison with our reports. Our estimates on total lysine requirements (for maintenance as well as gain) when expressed as \% requirement in diet is comparable to most of the reports on growing pigs as reviewed by NRC (1998) for pigs of similar weight. The present estimates of growth requirements are lower than the estimates $(0.018$ to $0.01943 \mathrm{~g} / \mathrm{g} \mathrm{ADG}$ ) of Yang et al. (1997a). The lysine requirements for growing pigs suggested by NRC (1998) were $1.35,1.15,0.95,0.75$ and $0.60 \%$ for 5 to 10,10 to 20,20 to 50,50 to 80 and 80 to $120 \mathrm{~kg}$ of live weight, respectively. Our estimates (when expressed as \% of diet) for 35 to 60 and 60 to $120 \mathrm{~kg}$ BW were comparable to NRC (1998) values but estimates for 7 to $20 \mathrm{~kg}$ and 20 to $35 \mathrm{~kg} \mathrm{BW}$ were slightly lower. The absolute lysine requirement values emanating from present study (Table 5) seem to be higher considering low lean growth rates. This can probably be attributed to the difference in genotype, diet and environment of the pigs causing less efficient absorption/utilisation of amino acids or by limiting response to nutrients leading to relatively higher maintenance requirements under tropical conditions

It has been shown that expression of amino acid requirements in terms of true digestible amino acid is better than in term of dietary total amino acid as digestibility of amino acid can vary with nature of ingredients. However, none of the reports analysed digestibility of amino acids probably because of difficulty in experimental methods required to estimate true amino acid digestibility. Hence, in the present study amino acid requirements have been derived and presented in term of total amino acid. Further, still today total amino acid values are used widely around the world including in India and good correlation was observed between dietary amino acid intake and performance of pigs across the database. This provides support to the fact that even if, requirement of dietary amino acid requirement is considered while formulating ration (until data are accrued on requirement of digestible amino acids), there will be increase in performance and improvement in economics of pig rearing.

The methionine + cystine requirements for growing pigs suggested by NRC (1998) were $0.76,0.65,0.54,0.44$ and $0.35 \%$ for 5 to 10,10 to 20,20 to 50,50 to 80 and 80 to $120 \mathrm{~kg}$ of live weight, respectively. The present estimates of dietary methionine + cystine requirements (when expressed as $\%$ of diet) were comparable with NRC (1998) values at lower BWs but were higher than NRC (1998) at higher BWs.

For other amino acids also, our estimates were comparable with NRC values at lower BWs but higher at higher BWs. No Indian data are available for comparison.

\section{Conclusion}

The present study provides estimates of nutrient requirements of growing Indian pigs reared under normal farm feeding conditions based on regression analysis of intake versus performance values reported from different feeding trials conducted across India involving different breeds under wide dietary and climatic situations. Based on criteria of variance of error estimate $\left(\sigma_{2}^{\text {error }}\right)$ and its standard error, CV of the model, BIC, significance level of the parameters estimated and $R^{2}$ values, prediction equations developed in the present study were valid and adequately accurate for predicting requirements under diverse conditions. These results suggest that the nutrient requirements derived in the present study can be used as a guide for feeding growing Indian pigs under diverse conditions prevailing in India. Utilisation of these requirements may result in the following benefits to the Indian pig industry: (1) increase in efficiency of nutrient utilization, (2) lowered feed costs, and (3) optimum weight gains with lowered stress on growing goats. However, the requirements presented here should be updated and refined further as more feeding trial data are generated on nutrient intake and production performance under different dietary and environmental situations.

\section{References}

Abate A 1989. Metabolizable energy requirements for maintenance of Kenyan goats. Small Ruminant Research 2, 299-306.

Agarwal DK, Pathak NN, Raina BL, Kumar D, Deo S and Chabra AK 1982. Note on the growth response of landrace pigs fed diets containing high levels of wheat bran. Indian Journal of Animal Science 52, 1141-1143.

Agricultural Research Council 1981. The nutrient requirements of pigs: technical review, revised edition. Common wealth Agricultural Bureaux, Slough, England.

Ash AJ and Norton BW 1987. Studies with the Australian cashmere goat. II. Effects of dietary protein concentration and feeding level on body composition of male and female goats. Australian Journal of Agricultural Research 38, 971-982.

Association of Official Analytical Chemists 1970. Official methods of analysis, 11 th edition. AOAC, Washington, DC.

Bhakt R, Gupta BS and Singh SK 1991. Urea treated sal (Shorea robusta) seed meal as a possible feed ingredient for growing pigs. Indian Journal of Animal Science 61, 769-771.

Bhar R 1998. Performance of crossbred pig fed on grainless diets. Ph.D. thesis, Indian Veterinary Research Institute.

Bohme H, Gadeken D and Oslage HJ 1980. Studies on energy costs of protein and fat deposition in early weaned piglets. Landwirtschaftliche Forschung 33, 261-271.

Broderick GA and Clayton MK 1997. A statistical evaluation of animal and nutritional factors influencing concentrations of milk urea nitrogen. Journal of Dairy Science 80, 2964-2971.

Campbell RG and Dunkin AC 1983. The effects of energy intake and dietary protein on nitrogen retention, growth performance, body composition and some aspects of energy metabolism of baby pigs. British Journal of Nutrition 49, 221-230.

Close WH and Stanier MW 1984. Effects of plane of nutrition and environmental temperature on the performance of growing finishing swine. Journal of Animal Science 54, 95-105.

Dhudapker BS, Chhabra SS and Ranjhan SK 1971. Effect of incorporation of different levels of digestible energy in growing finishing swine rations of Middle White Yorkshire pigs. Indian Journal of Animal Science 41, 1158-1162.

Food and Agriculture Organisation 2003. Production year book. Food and Agriculture Organisation, Rome.

Fuller MF, McWilliam R, Wang TC and Giles LR 1989. The optimum dietary amino acid pattern for growing pigs. 2. Requirements for maintenance and for tissue protein accretion. British Journal of Nutrition 62, 255-267. 
Gadeken D, Oslage HJ and Bohme H 1985. Energy requirement for maintenance and energy costs of protein and fat deposition in piglets. Archiv für Tierernährung 35, 481-494.

Hati UK, Sinha AP, Singh SK and Srivastava JP 2000. Effect of feeding marua (Eleusine coracana) as an energy source in the grower ration of Large White Yorkshire piglets. Indian Journal of Animal Science 70, 518-520.

Indian Council of Agricultural Research 1998. Nutrient requirements of domestic animals. Indian Council of Agricultural Research, New Delhi.

Kumar A, Thakur S, Srivastava JP and Singh SK 2000. Effect of replacing fish meal by soybean on digestibility, protein and minerals utilization in growing piglets. Indian Journal of Animal Science 70, 68-69.

McDonald P, Edward RA and Greenhalgh JFD 1995. Animal nutrition, fifth edition. Longman Singapore Publishers Pvt. Ltd, Singapore.

McNutt SD and Ewan RC 1984. Energy utilization of weanling pigs raised under pen conditions. Journal of Animal Science 59, 738-745.

Mandal AB, Paul SS, Mandal GP, Kannan A and Pathak NN 2005. Deriving nutrient requirements for growing Indian goats under tropical condition. Small Ruminant Research 58, 201-217.

National Research Council 1981. Nutrient requirements of goats: angora, dairy, and meat goats in temperate and tropical countries. National Academy of Sciences. National Academic Press, Washington, DC.

National Research Council 1998. Nutrient requirements of swine, 10th revised edition. National Academic Press, Washington, DC.

Noblet J and LeDividich J 1982. Effect of environmental temperature and feeding level on energy balance traits of early-weaned piglets. Livestock Production Science 9, 619-632.

Noblet J, LeDividich J and Bikawa T 1985. Interaction between energy level in the diet and environmental temperature on the utilization of energy in growing pigs. Journal of Animal Science 61, 452-459.

Okagbare GO, Nwokoro SO and Onagbesan OM 2004. Protein and energy requirements of pre-weaned West African Dwarf goats fed soyabean diet as a replacement for milk in a tropical environment. Tropical Animal Health and Production 36, 547-555.

Onwuka CFI and Akinsoyinu AO 1989. Protein and energy requirements for maintenance and gain by West African Dwarf goats fed cassava (Manihot utilissima) leaves with peels as supplement. Small Ruminant Research 2, 291-298.

Pathak NN and Ranjhan SK 1973. Nutrition studies with salseedmeal as a component of finisher rations in the Large White Yorkshire pigs. Indian Journal of Animal Science 43, 424-427.

Paul SS, Mandal AB, Kannan A, Mandal GP and Pathak NN 2003a. Comparative dry matter intake and nutrient utilization efficiency in lactating cattle and buffaloes. Journal of the Science of Food and Agriculture 83, 258-267.

Paul SS, Mandal AB, Mandal GP, Kannan A and Pathak NN 2003b. Deriving nutrient requirements of growing Indian sheep under tropical condition using performance and intake data emanated from feeding trials conducted in different research institutes. Small Ruminant Research 50, 97-107.

Paul SS, Mandal AB, Mandal GP, Kannan A and Pathak NN 2004. Deriving nutrient requirements of lactating Indian cattle under tropical condition using performance and intake data emanated from feeding trials conducted in different research institutes. Asian-Australian Journal of Animal Science 17, 769-776.

Paul SS, Mandal AB and Pathak NN 2002. Feeding standards for lactating riverine buffaloes. Journal of Dairy Research 69, 173-180.

Prasad N, Gupta BS and Singh SK 1991. Effect of feeding kosum (Schleichera oleosa) cake on the performance of growing crossbred pigs. Indian Journal of Animal Science 8, 111-114.

Rao ZP, Rao DS, Reddy RR and Reddy KK 1997. Nutrient digestibility and growth performance in pigs fed finisher ration supplanted with amaranthus forage. Indian Journal of Animal Nutrition 13, 210-211.

Ratray PV, Garret WN, East NE and Hinman N 1974. Efficiency of utilization of metabolizable energy during pregnancy and the energy requirements for pregnancy in sheep. Journal of Animal Science 38, 383-393.

Reddy BS, Prasad DA and Sreeramamurthy A 1981. Effect of replacing wheat bran with deoiled rice bran (W/W) or varying energy protein ratios on the performance and carcass characteristics of finisher Large White Yorkshire pigs. Indian Journal of Animal Science 51, 945-948.
Reddy BS, Prasad DA and Sreeramamurthy A 1982. Effect of varying protein and energy ratios on the performance of growing Large White Yorkshire pigs. Indian Journal of Animal Science 52, 236-240.

Schinchel AP and De Lange CFM 1996. Characterization of growth parameters needed as inputs for pig growth models. Journal of Animal Science 74, 2021. 2036.

Sharda DP, Pradhan K and Singh P 1976. A note on the effect of damaged pulses in the diet on the performance and carcass quality of growing finishing pigs. Indian Journal of Animal Science 46, 677-679.

Sharda DP and Sagar V 1986. Nutrient requirements of pigs. 1. Protein and energy requirements of growing and finishing pigs. Haryana Agricultural University Journal of Research 16, 325-329.

Sharda DP, Sagar V and Singh P 1982a. Effect of dietary protein levels on the growth, feed efficiency and carcass quality of pigs. Haryana Agricultural University Journal of Research 12, 1-5.

Sharda DP and Singh P 1981. Use of molasses and lucerne meal in diets for growing finishing pigs. Haryana Agricultural University Journal of Research 11, 583-587.

Sharda DP, Singh P, Sagar V and Pradhan K 1975. The effect of feeding lucerne meal in the diet on the performance and carcass quality of growing pigs. Haryana Agricultural University Journal of Research 5, 345-350.

Sharda DP, Singh P and Thakur RS 1982b. Protein levels for growing crossbred swine. Haryana Agricultural University Journal of Research 12, 164-167.

Sharda DP, Singh P and Yadav KR 1981. Performance and carcass quality of indigenous versus Middle White Yorkshire pigs from two to six months of age. Haryana Agricultural University Journal of Research 11, 117-120.

Sharda DP and Yadav KR 1982. A comparative study of the performance and carcass quality of exotic, crossbred and desi pigs from weaning to market. Haryana Agricultural University Journal of Research 12, 380-382.

Sharda DP and Yadav KR 1981. Effect of dietary protein levels on the performance of crossbred pigs. Haryana Agricultural University Journal of Research 11, 311-314.

Sharda DP and Yadav KR 1977. Effect of once or twice a day feeding during growing- finishing period on the performance and carcass characteristics of pigs. Haryana Agricultural University Journal of Research 7, 87-92.

Sharda DP, Yadav KR and Pradhan K 1979. Nutritive value of wheat bran for growing finishing pigs. Indian Journal of Animal Health 18, 13-16.

Solis G, Castellanos AF and Rodriguez GF 1991. Determination of nutritional requirement of growing hair sheep. Small Ruminant Research 4, 115-125.

Soren NM 2002. Performance of crossbred gilts fed on rice bran based diet. M.V.Sc. thesis, Indian Veterinary Research Institute.

Statistical Packages for the Social Sciences 2003. SPSS user's guide, version 12.0. SPSS Inc., New York.

Steele RJD and Torrie JH 1984. Principles and procedures of statistics, second edition. McGraw- Hill Book Co., New York, NY.

St-Pierre NR 2001. Invited review. Integrating quantitative findings from multiple studies using mixed model methodology. Journal of Dairy Science 84 , 741-755.

Walter JP and Mao IL 1989. Modelling net energy efficiencies as quantitative characteristics in lactating cows. Journal of Dairy Science 72 , 2362-2374.

Wenk C, Pfirter HP and Bickel H 1980. Energetic aspects of feed conversion in growing pigs. Livestock Production Science 7, 483-495.

Whittemore CT 1976. A study of growth responses to nutrient inputs by modeling. Proceedings of the Nutrition Society 35, 383-391.

Whittemore CT, Green DM and Knap PW 2001. Technical review of the energy and protein requirements of growing pigs: protein. Animal Science 73, 363-373.

Yadav BPS and Gupta JJ 1995. Nutritional values of rice polish in fattening pigs. Indian Journal of Animal Nutrition 12, 119-120.

Yadav BPS, Gupta HK and Gupta JJ 1995. Sweet potato (Ipomoea botatus L.) as a component of swine ration. Indian Journal of Animal Science 65, 455-459.

Yadav KR, Khirwar SS, Paliwal VK and Sharda DP 1982. Studies on the replacement of maize with hominyfeed in growing finishing swine rations. Haryana Agricultural University Journal of Research 12, 354-358.

Yadav BPS, Varma A and Gupta JJ 1993. Effect of feeding fodder radish (Raphanus sativus L.) as a partial replacement of concentrate component in swine rations. Indian Journal of Animal Science 63, 1202-1205. 
Yadav BPS, Varma A and Gupta JJ 1990. Green maize fodder feeding to pigs. Indian Journal of Animal Science 60, 1127-1128.

Yang CJ, Lee DW, Chung IB, Cho YM, Shin IS, Chae BJ, Kim JH and Han IK 1997a. Developing model equation to subdivide lysine requirements into requirements for growth and maintenance in pigs. Asia-Australian Journal of Animal Science 10, 54-63.
Yang CJ, Lee DW, Chung IB, Cho YM, Shin IS, Chae BJ, Kim JH and Han IK 1997b. Developing model equation to subdivide methionine + cystine requirements into requirements for growth and maintenance in pigs. Asia-Australian Journal of Animal Science 10, 86-97.

Zhang B and Coon CN 2000. Modelling metabolisable energy utilization in laying hens. Proceedings of the British Society of Animal Science 2000, pp. 89-92. 